\title{
Emotional Connotation Research on College Campus Landscape Sculpture
}

\author{
Xiaoyan Weng \\ Huanggang Normal University \\ Huanggang, China
}

\begin{abstract}
The college campus is the most concentrated area of the urban culture and the elite. As the important material carrier of campus space culture, the sculpture landscape is particularly important. However, some of the current campus sculptures only pay attention to the superficial effect, but lack of the focus on emotional level needs. Only with the emotional power can sculpture landscape form the attractive special region. Only with the humanistic care can the landscape situation move people with emotion and achieve the realm with the scenery depicted and the emotions expressed in perfect harmony, so as to achieve the effect of recessive psychological education in the tacit understanding. In conclusion, the author hopes to make some analysis and study in the following four aspects: historic feelings, cultural complex, aesthetic emotion and education situation. And it is expected to provide constructive suggestions on the current college campus sculpture landscape planning, design and practice.
\end{abstract}

Keywords-college campus; sculpture landscape; emotion; aestheticism; history; culture; education

\section{INTRODUCTION}

Impact on the environment restricts the people's behavior psychology. As the most advanced cultural space, the good benefit of college campus space environment directly affects the comprehensive quality of the university and the all-round development of students, the campus sculpture landscape is the material form of the most refined refreshing campus environment. It has the most obvious visual impact and artistic appeal. Excellent campus sculpture expresses the humanistic spirit and cultural connotation in school which has been accumulated as the time passes, thus having the invisible power, moving people with emotion and touch people's heart. It has the invisible effect on the coordinate development of college students' aesthetic cognition, emotion and will. It is also the internal and profound lasting. It is the curing of hidden curriculum of schools and can achieve the effect of recessive psychological education in the tacit understanding.

The scholar Li Fuquan interpret, "the college campus sculpture is the real art form, taking the natural material as the carrier, created with the different material, form and methods of processing, integrated with the author's subjective emotion. It is the sculpted art to express people's deep emotions. And ultimately, it will be integrated with the surroundings and the culture as an organic whole." ${ }^{[1]}$ As the sculpted symbol of the cultural elite, the campus sculpture stands in the beautiful

Humanity and social science project of Department of Education of Hubei Province, Project No. 13g415. campus, forms an attractive space. The attention of the college students will focus on the color of the surface, the inherent material, the modeling and other external factors. Then the feeling and thought will form through sensory interaction, and finally the attitude and experience will form. They may recall, contemplate, reflect or inspire. The scene and feeling will be coherent in the heart and long for each other. The author will make some analysis and study in the following four aspects: historic feelings, cultural complex, aesthetic emotion and education situation of the sculpture landscape.

\section{HISTORIC FEELINGS}

Like cities, each university has its own long history. The college campus landscape is the material carrier of the campus history culture. Campus sculpture is one of the most refined, the most lasting and the most intuitive form. In the unique artistic language, the arts directly or indirectly record the historical events, proclaim the humanistic spirit and express the feelings of history.

For the campus sculpture molded at different stage in the campus history, it is a kind of historical testimony. The mottled surfaces and the form of nostalgia exude a vicissitudes of the years and send a heavy feeling of history. In the long term, the history and culture connotation of the campus enters into the hearts of the students invisibly.

As one of the symbols of Tsinghua University, the sundial "Fig. 1" is the memorial sent students of 1920 (Gengshen) session when they graduated. With time passes, it stands across from the auditorium as a wise old man. In the past one hundred years, it has witnessed the history and development of Tsinghua University, accumulated the strong historical and cultural background, becoming a unique spiritual wealth of the university. 


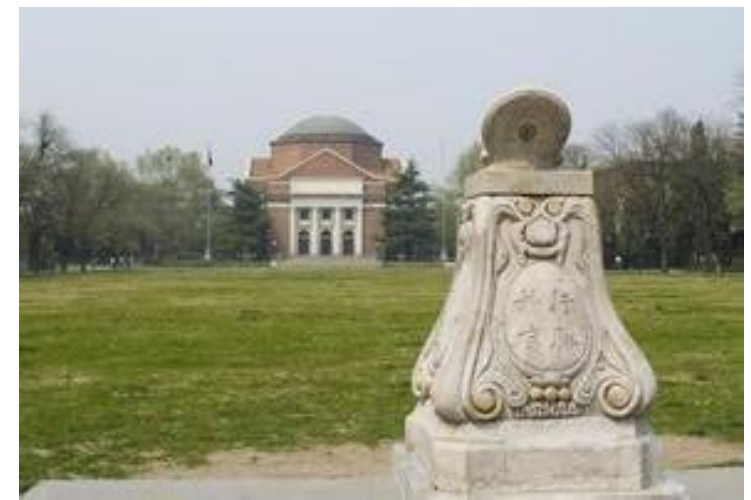

Fig. 1. Tsinghua University, the sundial

In the development, many universities have preserved the used school gate or plaques, and then designed reasonably and cleverly into the new campus construction, thus having a historic commemorative value and inheriting the historic culture connotation. For example, the second gate of Tsinghua University is primarily used to be its main gate "Fig. 2", founded in 1909, it is not just the bright symbol of Tsinghua, but also the symbol of the diligent and peaceful mind and character developed in a long time. When the newly built college of Shenyang Architectural University "Fig. 3" relocated, it preserved and relocated the old school gate founded in 1954 to the new campus. After several changes, the old school gate became the most historic scene among the many sculpture landscape of the new college. China Academy of Art copied and carved the horizontal inscribed board "the National Academy of Art" personally inscribed by Cai Yuanpei in 1928, placed in each school doorway to reveal the long history of the college.

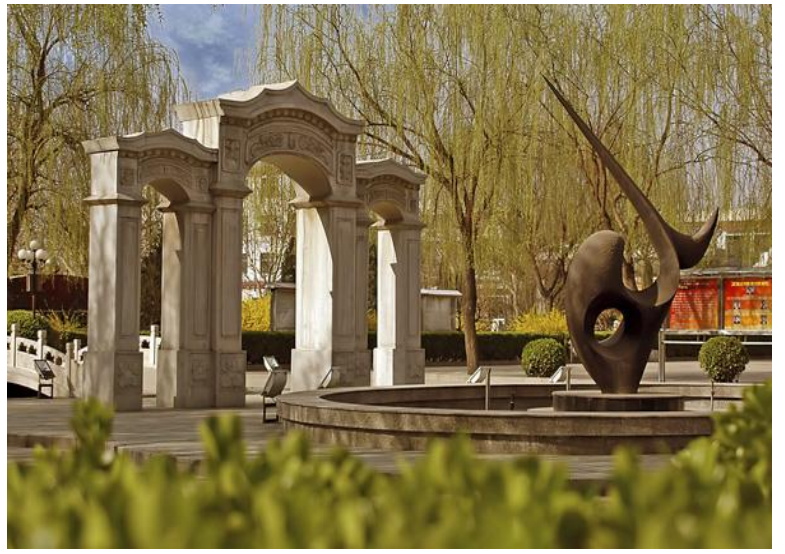

Fig. 2. The second gate of Tsinghua University

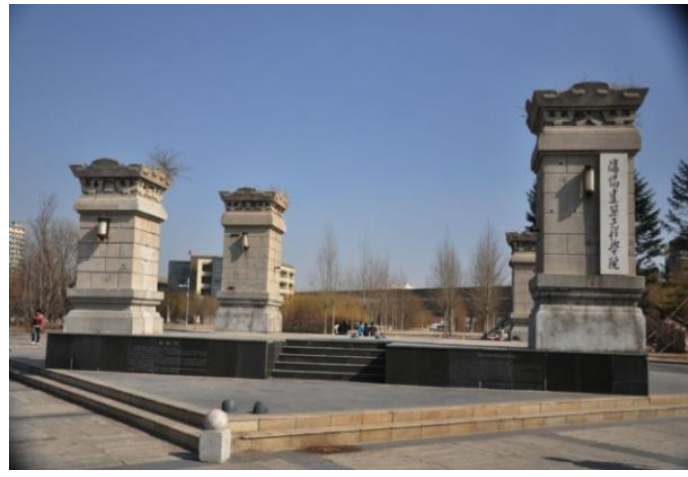

Fig. 3. The old school gate of Shenyang Architectural University

In the designing of new campus sculpture, a connotative or soul artist shall fully tap the campus's history, culture and all of the rest related factors, respect for history and tradition, especially the commemorative sculpture, which may commemorate a significant event or a character. In 1986, to mark the 40th sacrifice anniversary of Wen Yiduo, Tsinghua University set up Wen Yiduo Statue "Fig. 4". It is a red granite stone cave. There is a black rock wall where inscribes with his famous words, "the main gift of a poet is love, love his motherland and people. He is a sign of school spirit, and also is the epitome of the history progress". Wen Yiduo Statue is designed briefly in concise style. With several drawings, the Statue is depicted exactly and vividly. There have been thirty years since then, successive Tsinghua students have been influenced by what they constantly see and hear. The historical feeling closes the distance between time and space. The integrity of the poet and Tsinghua character got inheritance.

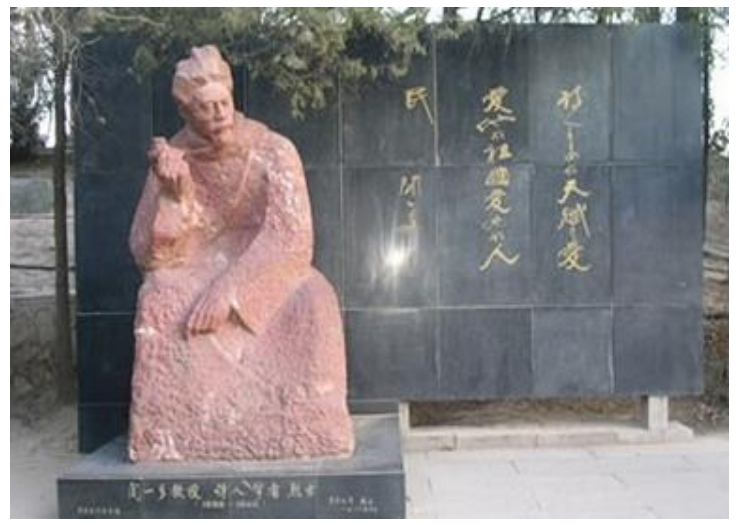

Fig. 4. Wen Yiduo Statue

\section{Cultural COMPLEX}

College campus culture is a kind of atmosphere, a kind of invisible power, the carrier of university spirit, a high-quality university spiritual character with long-term accumulation. College campus sculpture is the combination of spiritual and material culture. As the college campus humanity landscape, sculpture should fully embody the special campus culture spirit and express a kind of university culture connotation. Culture is the soul of a university, a stable spiritual wealth of a university forming in a long time and it has the unique charm. Artists, using traditional or modern, concrete or abstract technique, 
combined with the spirit of the history and the times, create the sculpture landscape that can show the campus culture, which can show the features of the campus, carry forward the spirit of the Chinese national culture. People will get a certain amount of cultural information by appreciating, tasting and interpreting the image of the sculpture over a long period.

On the centenary of Tsinghua University, the international campus sculpture exhibition with the theme "humanity science art", the "Wings" by Zhang Songzheng was sculptured with copper and stainless steel, two kinds of materials. The sculpture looks like an opening door "Fig. 5", and also like two trees, representing the eastern and western cultures. Its conception expresses the school-running characteristics of Tsinghua University - Western and Chinese-compatible, the past and present-connected, mutual infiltration of art and science, combination of science with technology ". In the form of a specific objects, it interprets the cultural intension and campus culture orientation of Tsinghua University. It is with extraordinary culture conveying meaning. And it is a kind of campus sculpture image creation activity with cultural complex.

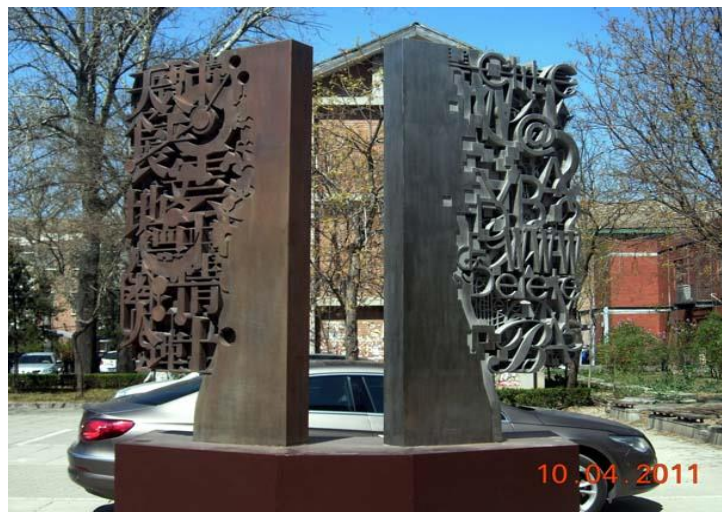

Fig. 5. Tsinghua University Wings

\section{AESTHETIC EMOTION}

Art is "the consciousness form reflecting the social life by composing specific and vivid image. It relies on the image to reflect people's understanding of social life, including the understanding, emotion, wish and will, grasp and recreate the social life in accordance with the aesthetic rules, and affect people's thought, emotion and social life through the aesthetic infection." Marx's this conclusion applies to the sculpture art.

College campus sculpture landscape is the art image with entity. The artists make artistic with a concept of art and artistic processing. They use the various natural or synthetic material to create the sculpture. And by the monomer model, volume, spatial characteristics, color, light and other factors, using the rhythm, order, structure and other aesthetic principles, the artists will sculpt the specific and perceived monomer and combination of the image, which condenses the judgment of beauty for artists as well as the expression of the emotional implication. It is highly integrated with the environment at the same time, constituting the whole atmosphere of harmony and clever. These works of art show originality, concrete or abstract, both with surface and inner beauty. Some praise a character's lofty image; some show a kind of upward spirit, or just a smile. All of the images promote the students' aesthetic emotion.

The conveyance and acceptance between sculpture landscape and aesthetic subjects, is actually a kind of exchange and dialogue. In the process, perception plays a vital role. Campus is the gathering place for cultural elites. Generally, the appreciator has profound culture knowledge and a certain aesthetic ability. The aesthetic subjects produce feeling and thinking through sensory interaction. And their different experience and visual experience of life will have an effect on the aesthetic emotion. "There are a thousand Hamlets in a thousand people's eyes", thus bringing unique aesthetic experience to each individual, and forming deep-seated emotional communication.

At the same time, the sculpture is perceptive, can bring people with participative and all-round aesthetic experience. Mr. Li Weisi hosted to create the sculptured group Chen Jiageng and His Students "Fig. 6", as a gift for Xiamen University's 80 anniversary. This sculptured group represents the situation where Mr. Chen takes a talk to the students. The modeling is realistic and lifelike, which concentrate a profound humanistic spirit into a simple action. At the same time, the proportion is as big as the real man. And in the whole layout, the incomplete scatter composition is used on purpose. Thus forming an open and participative space, where just like Mr. Chen Jiageng, the "master" has been with us, seemingly insipid, but it is of far-reaching conception, and is inadvertently touching.

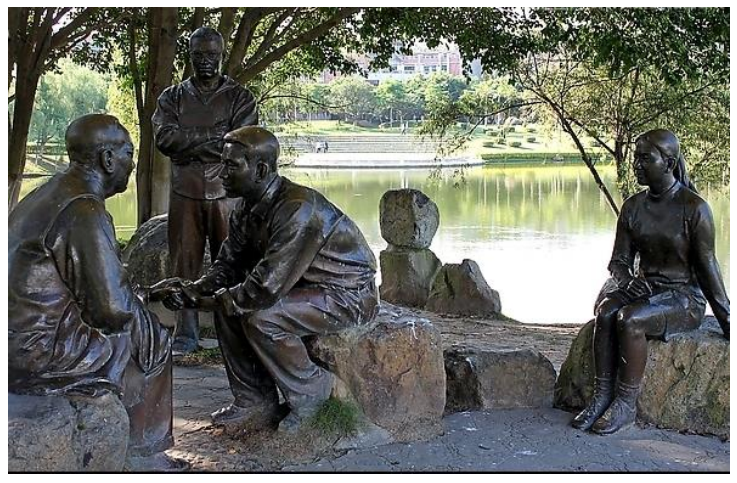

Fig. 6. Xiamen University Chen Jiageng and His Students

\section{EDUCATION SituATION}

The special characteristic of the university determines its task - to cultivate and teach people. As the most condensed pattern of manifestation of material carrier of university campus culture, the building of campus sculpture plays an irreplaceable role in college students' education. Yang Zhenning said: "campus sculpture has a great impact on students. Both the realistic and abstract sculptures will become part of their college life in a few years. In their memory, sculpture often has more long-term effect than buildings because the sculpture usually has a deep abstract sense of sublimation. " Sculpture is just like a" silent teacher with his own style", who will maximize play his silent and moving part in teaching college students subtly. 
In the opinion of the American Deberry, campus sculpture has a very high aesthetic value and function of education. Excellent campus sculpture has a meaningful aesthetic feeling from its shape to material, which could improve the students' aesthetic ability, and be advantageous to the students to burst with feelings of love in the aspects of appreciating and creating beauty. At the same time, the education with leavening effect can help students turn the beauty of the outside world into the beauty of the mind and behavior.

What is more, excellent campus sculpture can build a good education situation, thus having good moral cultivation and education benefits. In class, we teach knowledge, and the campus physical environment also plays an important part as education. The visual focus formed with campus sculpture integrates with the surrounding buildings and the environment space as a whole, which is essentially the focus of campus spiritual life, a vision of the character of the campus, the times spirit of a region. And a good environment of campus culture and spiritual atmosphere is built with the aid of the sculpture. In such situation, the communication, meditation and rest are all the process to acquire knowledge, edify sentiment and inherit culture. The college campus sculpture infuses into the interactive cultural environment and spiritual atmosphere, expresses the distinctive campus culture of each university, contains the education purpose, and deeply influences the students' value orientation, ideology, way of thinking, behavior patterns and other aspects in individual development. When dream, faith, moral, wisdom, truth, democracy and freedom are closely linked with the experience between the teachers and students by sculpture landscape and their perception, the teachers and students can deeply feel heartfelt admiration, and their desire to construct their own lofty personality may be sparked, thus forming the most successful education.

\section{CONCLUSION}

Though like cold object, the excellent campus sculpture can be full of emotional connotation and has an invisible force, which could create an attractive region of space together with other campus landscape, and create a landscape situation full of humanistic care, thus affecting the generation after generation of kids with the emotional power and kindly influence.

\section{REFERENCES}

[1] Jing Qimin, Zhang Li'an. The emotional construction [M]. Tianjin: Baihua Literature and Art Publishing House, 2004.

[2] Written by Tadao Ando and translated by Bai Lin. The theory of Tadao Ando on architecture [M]. Beijing: China Architecture \& Building Press, 2003.

[3] Ma Tieding. Environmental psychology and psychological environment [M]. Beijing: National Defence Industry Press, 1996.

[4] Zhang Peng. The study of the invisible value of the visual culture [M]. Beijing: People's Education Press, 2008.

[5] Wang Youwen. My view on campus sculpture of institution of higher education [J]. China Higher Education Research, 1998 (3) : 53-54. 